\title{
Responses of growth inhibition and antioxidant gene expression in earthworms (Eisenia fetida) exposed to tetrabromobisphenol A, hexabromocyclododecane and decabromodiphenyl ether
}

\author{
Ya-juan Shi ${ }^{\mathrm{a}}$, Xiang-bo $\mathrm{Xu}^{\mathrm{b}}{ }^{\mathrm{b}}$, Xiao-qi Zheng ${ }^{\mathrm{c}}$, Yong-long Lu ${ }^{\mathrm{a}, *}$ \\ a State Key Laboratory of Urban and Regional Ecology, Research Center for Eco-Environmental Sciences, Chinese Academy of Sciences, Beijing 100085, China \\ b Beijing Municipal Environmental Monitoring Center, Beijing 100048, China \\ c National Center for Climate Change Strategy and International Cooperation, Beijing 100038, China
}

\section{A R T I C L E I N F O}

\section{Article history:}

Received 17 May 2015

Received in revised form 16 June 2015

Accepted 17 June 2015

Available online 25 June 2015

\section{Keywords:}

Brominated flame retardants

TBBPA

$\mathrm{HBCD}$

BDE 209

Growth inhibition

Gene expression

Antioxidant enzymes

Heat shock proteins

\begin{abstract}
A B S T R A C T
Tetrabromobisphenol A (TBBPA), hexabromocyclododecane (HBCD) and decabromodiphenyl ether (BDE 209), suspected ubiquitous contaminants, account for the largest volume of brominated flame retardants (BFRs) since penta-BDE and octa-BDE have been phased out globally. In this paper, the growth inhibition and gene transcript levels of antioxidant enzymes (superoxide dismutase (SOD), catalase (CAT)) and the stress-response gene involved in the prevention of oxidative stress (Hsp70) of earthworms (Eisenia fetida) exposed to TBBPA, HBCD and BDE 209 were measured to identify the toxicity effects of selected BFRs on earthworms. The growth of earthworms treated by TBBPA at 200 and $400 \mathrm{mg} / \mathrm{kg} \mathrm{dw}$ were inhibited at rate of $13.7 \%$ and $22.0 \%$ respectively, while there was no significant growth inhibition by HBCD and BDE 209. A significant $(P<0.01)$ up-regulation of SOD expression level was observed in earthworms exposed to TBBPA at $50 \mathrm{mg} / \mathrm{kg} \mathrm{dw}$ (1.77-fold) and to HBCD at $400 \mathrm{mg} / \mathrm{kg} \mathrm{dw}$ (2.06-fold). The transcript level of Hsp70 gene was significantly up-regulated $(\mathrm{P}<0.01)$ when earthworms exposed to TBBPA at concentration of 50-200 mg/kg (2.16-2.19-fold) and HBCD at $400 \mathrm{mg} / \mathrm{kg}$ (2.61-fold). No significant variation of CAT gene expression in all the BFRs treatments was observed, neither does all the target gene expression level exposed to BDE 209. Assessed by growth inhibition and the changes at mRNA levels of encoding genes in earthworms, TBBPA showed the greatest toxicity, followed by HBCD and BDE 209, consistent with trends in molecular properties. The results help to understand the molecular mechanism of antioxidant defense.
\end{abstract}

(c) 2015 Elsevier Inc. All rights reserved.

\section{Introduction}

Brominated flame retardants (BFRs) are synthetic chemicals used globally to reduce the likelihood of ignition of materials and/or decrease the rate of combustion. The production and use of penta-BDE, octa-BDE, and some other BFRs have been banned regionally, e.g. in European Union, North-East Atlantic countries or even worldwide since they are listed as or suspected to be persistent organic pollutants (Kemmlein et al., 2009; Covaci et al., 2011; Ni et al., 2013). Currently, tetrabromobisphenol A (TBBPA), hexabromocyclododecane (HBCD) and decabromodiphenyl ether (BDE 209, the fully brominated congener of poly-brominated diphenyl ethers, PBDEs) account for the largest volume of BFRs. However, they have been identified to be ubiquitous contaminants where employed by the elevated concentration in biota tissues and abiotic matrices (e.g. in air, indoor dust, water, soil, sewage sludge, sediments etc.) and their thyroid hormone disrupting, endocrine disrupting toxicity, neurotoxicity, reproductive and development

\footnotetext{
* Corresponding author. Tel.: +8610 62849118; fax: +861062918177.

E-mail address: yllu@rcees.ac.cn (Y. Lu).
}

toxicity (de Wit et al., 2006; Gauthier et al., 2007; Law et al., 2008 , 2014; Covaci et al., 2009, 2011).

Soils are a major reservoir and sink for PBDEs, HBCD and other BFRs because of their high octanol-water partition coefficient, low water solubility and low vapor pressure (Covaci et al., 2006; Yang et al., 2010; Gevao et al., 2011). Therefore, soils play an important role in the distribution and biogeochemical cycling of the BFRs, the effects of these BFRs on terrestrial invertebrates, with earthworms as the model species, which live in the soils in the whole or part of the life cycle could be the subject of intensified research.

Organisms remove reactive oxygen species (ROS) and then defend oxidative stress by antioxidative enzymes such as catalase (CAT), superoxide dismutase (SOD), and peroxidase (POD). Stress-responsive proteins such as heat shock protein 70 (Hsp70) also protect the cell from the toxin (Homa et al., 2005, 2007; Chen et al., 2011a). Evidence indicate that the induction of the antioxidant enzymatic system and Hsp70 may serve as potential biomarkers of environmental pollution in toxicology (Song et al., 2009; Webb and Gagnon, 2009; Xue et al., 2009; Zhang et al., 2009). Gene expression profiling is a useful supplement for protein level detection, as the mRNA level represents a snapshot of the 
cell activity, and has been performed to better identify biomarkers of toxicity to predict potential hazardous chemicals (Olsvik et al., 2005; Brulle et al., 2010). Previous research has detected that the gene expression of antioxidant enzymes and Hsp70 in earthworms is involved in the oxidative stress responses to heavy metals (Homa et al., 2007; Brulle et al., 2010; Xiong et al., 2014) and organic chemicals (Chen et al., 2011a,b). Reports indicated that BDE 209 and TBBPA induced the ROS and activities of selected antioxidant enzymes in earthworms (Xue et al., 2009; Xie et al., 2011; Zhang et al., 2014), however, little is known about the transcriptional regulation of antioxidant and stressresponse gene at the mRNA level with respect to the response of earthworms to HBCD, BDE 209 and TBBPA, and warrant more thorough investigation.

In this paper, the growth inhibition and gene expression levels of SOD, CAT and Hsp70 of earthworms (Eisenia fetida) exposed to TBBPA, HBCD and BDE 209 were detected to identify the toxicity effects of selected BFRs on earthworms. The study may help to understand the molecular mechanism of antioxidant defense and provide early markers for the toxic damage of cellular proteins by assessing the changes in mRNA levels of encoding antioxidant enzyme genes and stress induced proteins involved in the prevention of oxidative stress.

\section{Materials and methods}

\subsection{Earthworms and chemicals}

Mature earthworms (E. fetida) of age 3 months with a welldeveloped clitellum were obtained from a farm in Beijing. They were removed from the soil $24 \mathrm{~h}$ before use and stored in Petri dishes on damp filter paper (in the dark at $20 \pm 1{ }^{\circ} \mathrm{C}$ ) to void their gut contents.

Decabromodiphenyl ether (BDE 209) (CAS No. 1163-19-5, 98\% purity) was purchased from J\&K Scientific Chem Service (China). Tetrabromobisphenol A (CAS No. 79-94-7, 98\% purity), was produced by TCI (Shanghai) Chemicals; hexabromocyclododecane (CAS No. 3194-55-6, 95.0\% purity), was produced by TCI Chemicals (Japan). Nhexane (analytical grade) was purchased from Sinopharm Chemical Reagent Co, Ltd. (SCRC) (Shanghai, China). All the other chemicals and reagents (analytical grade) were also purchased from Sinopharm Chemical Reagent Co, Ltd. (SCRC) (Shanghai, China). All aqueous solutions were prepared by using reagent water from a Milli-Q Gradient system (Millipore Company, Bedford, USA).

\subsection{Acute toxicological tests}

The earthworm cultivation method followed the guideline of the OECD method (OECD 1984). The artificial soils consisted of 70\% quartz sand, $20 \%$ kaolin clay and $10 \%$ sphagnum peat and the moisture content was adjusted to about $35 \%$ by adding deionized water. The $\mathrm{pH}$ is adjusted to $6.0 \pm 0.5$ with calcium carbonate.

BDE 209 was spiked with n-hexane $(20 \mathrm{ml})$ as a carrier and thoroughly mixed into the artificial soils at concentrations of $0,1,10,100$ and $200 \mathrm{mg} / \mathrm{kg}$ dry soil. TBBPA and HBCD were dissolved with $20 \mathrm{ml}$ acetone and thoroughly mixed into the soils at concentrations of 0,50 , 100,200 , and $400 \mathrm{mg} / \mathrm{kg}$ dry soil, respectively. Four replicates were used for each dose; $750 \mathrm{~g}$ of wet artificial soils was added to each container. Controls and solvent controls were four containers with BFRs replaced by deionized water or acetone. Before introducing the earthworms, every container was placed in an exhaust hood for 24 days to ensure that the n-hexane or acetone had completely evaporated. 10 earthworms $(0.35-0.45 \mathrm{~g}$ each $)$ were then placed into each container. The containers were kept in an incubation chamber $\left(20 \pm 1{ }^{\circ} \mathrm{C}\right)$, $83 \pm 3 \%$ relative humidity with continuous illumination at $400-800 \mathrm{~lx}$ throughout the test period.

During the period of exposure, earthworms were taken from the containers, cleaned with deionized water, weighed, and then put back to the containers at days $4,7,10$, and 14 . After exposure for 14 days, three earthworms were selected from each container randomly to be used to determine gene expression levels, respectively.

\subsection{Growth inhibition of earthworms}

The growth inhibition rate (GIR, \%) and instantaneous growth rate $\left(\right.$ IGR, $\mathrm{d}^{-1}$ ) were calculated as:

$\mathrm{GIR} n=\frac{\mathrm{W}_{0}-\mathrm{W}_{14}}{\mathrm{~W}_{0}} \times 100 \%$

$\operatorname{IGRn}=\frac{\ln \mathrm{W}_{j}-\ln \mathrm{W}_{i}}{\mathrm{t}_{j}-\mathrm{t}_{i}}$

where GIR $n$ is the growth inhibition rate for dose group $n$ during the $14 \mathrm{~d}$ exposure period, IGRn is the instantaneous growth rate for dose group $n$ from day $i$ to $j, W_{0}$ is the weight on day $0, W_{14}$ is the weight on day $14, W_{i}$ is the weight on day $i$ and $W_{j}$ is the weight after $j$ days of exposure.

\subsection{Gene transcript levels}

Earthworms which were selected from each container randomly cleaned with deionized water, left in petri dishes with moist filter paper to clear out their gut contents for $24 \mathrm{~h}$ and then ground immediately in liquid nitrogen. All expression analyses were conducted on total RNA isolated using the TRIzol Reagent (Invitrogen, USA), according to the manufacturer's instructions. RNA purity and integrity were measured by agarose gel electrophoresis (2\%) to ensure that absorbance ratios $\left(A_{260 / 280}\right)$ were between 1.8 and 2.0. First-strand cDNA synthesis was performed using a superscript ${ }^{\mathrm{TM}}$ IIreverse transcriptase (Invitrogen, USA), according to the manufacturer's instruction. Reverse transcription and quantitative PCR (RT-qPCR) of the selected genes ( $\beta$-actin, SOD, CAT and Hsp70) were conducted using the Real-Time PCR kit (TaKaRa, Japan).

The Mastermix contained (final concentrations) the following: $2.0 \mu \mathrm{l}$ cDNA template, $0.4 \mu \mathrm{l}$ each of forward and reverse primer (concentration of $10 \mu \mathrm{M}), 6.8 \mu \mathrm{ddH}_{2} \mathrm{O}, 10 \mu \mathrm{l}$ SYBR ${ }^{\circ}$ Premix Ex Taq ${ }^{\mathrm{TM}}(2 \times)$ and $0.4 \mu \mathrm{l}$ ROX Reference Dye $(50 \times)^{*} 2$ (TaKaRa, Japan). The following RTqPCR reactions were performed with the 7300 Real-Time PCR system (ABI, USA): initial denaturation step $\left(95^{\circ} \mathrm{C}, 10 \mathrm{~min}\right)$, amplification and quantification step repeated 40 times $\left(95^{\circ} \mathrm{C}\right.$ for $15 \mathrm{~s}$, annealing temperature $55^{\circ} \mathrm{C}$ for $15 \mathrm{~s}, 72^{\circ} \mathrm{C}$ for $45 \mathrm{~s}$ ) and melting curve step (one cycle of $95{ }^{\circ} \mathrm{C}$ for $15 \mathrm{~s}, 55^{\circ} \mathrm{C}$ for $30 \mathrm{~s}$, and $95^{\circ} \mathrm{C}$ for $15 \mathrm{~s}$ ).

Sequence of primers used for RT-qPCR is shown in Table 1. Primers of $\beta$-actin, SOD, CAT and Hsp70 used for earthworms (E. fetida) were selected from references (Brulle et al., 2006; Chen et al., 2011b).

Table 1

Sequence of primers used for RT-qPCR.

\begin{tabular}{|c|c|c|c|}
\hline Gene & Accession number & Forward primer & Reverse primer \\
\hline$\beta$-actin & GU177854 & 5'-TCCATCGTCCACAGAAAG-3' & 5'-AAATGTCCTCCGCAAGCT-3' \\
\hline SOD & GU177856 & 5'-TGCTCACTTCAACCCATTT-3' & 5'-TTGGCAACACCACTTTCA-3' \\
\hline CAT & GU177857 & 5'-CATTGCGGATGGAAACTA-3 & 5'-CCAAGGACAACAACCTGCTC- ${ }^{\prime}$ \\
\hline Hsp70 & GU177858 & 5'-CCAAGGACAACAACCTGCTC-3' & 5'-CGGCGTTCTTCACCATTC-3' \\
\hline
\end{tabular}


The efficiencies (E) of amplification of target gene and reference gene were calculated from the given slope of the standard curve according to the equation $E=10^{(-1 / \text { slope })}-1$. They were in the ranged from 0.98 to 1 (Pearson correlation coefficient $r^{2}>0.99$ ), and a strong linearity was observed.

The relative quantification of target genes with reference gene (R) was calculated according to the formula $\mathrm{R}=\left(\mathrm{E}_{\mathrm{Tg}}\right)^{\mathrm{CPTg}} /\left(\mathrm{E}_{\mathrm{act}}\right)^{\mathrm{CPact}}$, target gene (Tg), $\beta$-actin gene(act) (Pfaffl, 2001; Brulle et al., 2006).

\subsection{Statistical analysis}

The data for growth inhibition and gene expression levels were each subjected to a one-way analysis of variance (ANOVA) calculating the LSD to contrast the differences between treatment means, with assuming a normal distribution and the homogeneity of variances, which were tested respectively by the Shapiro-Wilk test and Levene's test. The paired sample t-test was applied to the instantaneous growth rates to test the differences of the growth rates in the different intervals. Logarithmic transformation was applied to the dependent variables in gene expression levels analysis. The Pearson correlation was used in correlation analysis. A probability level of 0.05 was used in all procedures (equivalent to $95 \%$ confidence) and data were presented as means \pm standard deviation (SD). All statistical analyses were performed using SPSS $18.0^{\circ}$ software and all charts were designed using Origin 8.6 software.

\section{Results}

\subsection{Growth inhibition}

The growth inhibition rates of earthworms exposed to TBBPA, HBCD and BDE-209 over 14 days are shown in Fig. 1. Growth inhibition rates of earthworms exposed to TBBPA were shown to be dosedependent over 14-day ( $\mathrm{P}<0.01)$. The growth inhibition of earthworms treated with the higher doses (200 and $400 \mathrm{mg} / \mathrm{kg} \mathrm{dw}$ ) was significantly higher than those for treatments at the controls and lower concentrations $(50,100 \mathrm{mg} / \mathrm{kg} \mathrm{dw})(\mathrm{P}<0.05)$. However, no significant concentration-related growth inhibition in earthworms from exposure to HBCD and BDE 209 was observed $(P>0.05)$.

The instantaneous growth rates of the earthworms exposed to TBBPA during the $0-14$ th days are shown in Fig. 2a. The negative growth rates portended growth inhibition of earthworms. The growth rates during $0-4$ th day of all groups were significantly lower than those during 4th-7th and 7th-10th days $(P<0.01)$, and they showed negatively dose-dependent during each of the intervals, the minimum value appeared at the concentration of $400 \mathrm{mg} / \mathrm{kg} \mathrm{dw}(\mathrm{P}<0.05)$. The growth rates increased after the 4th day, becoming of positive values in the groups of controls and low doses $(50 \mathrm{mg} / \mathrm{kg} \mathrm{dw})$.

The negative growth rates of earthworms exposed to HBCD appeared during the $0-4$ th day and 10 th-14th day, the growth rates during $0-4$ th day of all groups were significantly lower than those during 4-7th and 7th-10th days $(\mathrm{P}<0.01)$, however, no significant difference was obtained between the HBCD treatments and controls during each of the intervals ( $P>0.05)$ (Fig. 2b).

The negative effect on growth rates of earthworms exposed to BDE 209 appeared during the whole 14 days, the growth rates during 0 4th day of all groups were significantly higher than those during all the other intervals $(P<0.01)$, no significant difference among different BDE 209 dose groups was shown during each of the exposure period $(\mathrm{P}>0.05)$ (Fig. 2c).

\subsection{Gene expression levels}

Transcriptional levels of target genes (SOD, CAT and Hsp70) of earthworms exposed to TBBPA are shown in Fig. 3. No significant variations of CAT gene expression level between TBBPA treated groups and controls, deionized water $(\mathrm{CK})$ and acetone control (CKs), were observed ( $\mathrm{P}>0.05)$. Transcriptional levels of SOD and Hsp70 genes showed significant variations between TBBPA dose groups and the controls throughout the 14-day acute tests. With the increase of the concentrations, up-regulation of SOD expression level was observed in earthworms, significant up-regulation of SOD gene expression level appeared at the concentration of $50 \mathrm{mg} / \mathrm{kg} \mathrm{dw}$ (1.77-fold, $\mathrm{P}<0.01$ ). Earthworms exposed to TBBPA expressed a significant up-regulation of Hsp70 gene expression levels $(50 \mathrm{mg} / \mathrm{kg} \mathrm{dw}$, 2.19-fold, $\mathrm{P}<0.01 ; 100 \mathrm{mg} / \mathrm{kg} \mathrm{dw}, 2.17$-fold, $\mathrm{P}<0.01 ; 200 \mathrm{mg} / \mathrm{kg} \mathrm{dw}$, 2.16-fold, $\mathrm{P}<0.01$ ).

Transcriptional levels of target genes (SOD, CAT and Hsp70) of earthworms exposed to HBCD are shown in Fig. 4. With increase of the concentrations, up-regulation of SOD and Hsp70 expression level was observed in earthworms. Significantly, higher level of SOD and Hsp70 gene expression level appeared at the concentration of $400 \mathrm{mg} / \mathrm{kg} \mathrm{dw}$ (SOD, 2.06-fold, $\mathrm{P}<0.01$; Hsp70, 2.61-fold, $\mathrm{P}<0.01$ ). No significant variations of CAT gene expression level between HBCD treated groups and controls were observed $(\mathrm{P}>0.05)$.

Transcriptional levels of target genes (SOD, CAT and Hsp70) of earthworms exposed to BDE-209 showed variations between control and BDE-209 treated groups, however no significant differences $(P>0.05)$ were detected for all the target genes (Fig. 5).

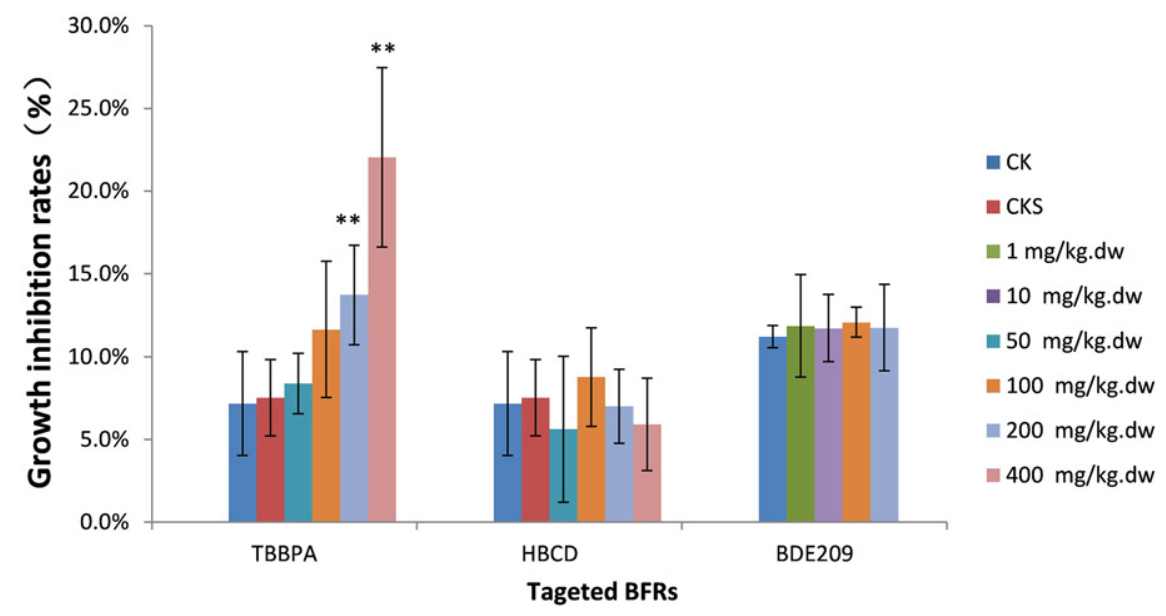

Fig. 1. Growth inhibition rates of earthworms exposed to TBBPA, HBCD and BDE-209 over 14 days ( ${ }^{* *} \mathrm{P}<0.01$ compared with the control groups). 
(a) TBBPA

Exposure interval (d)

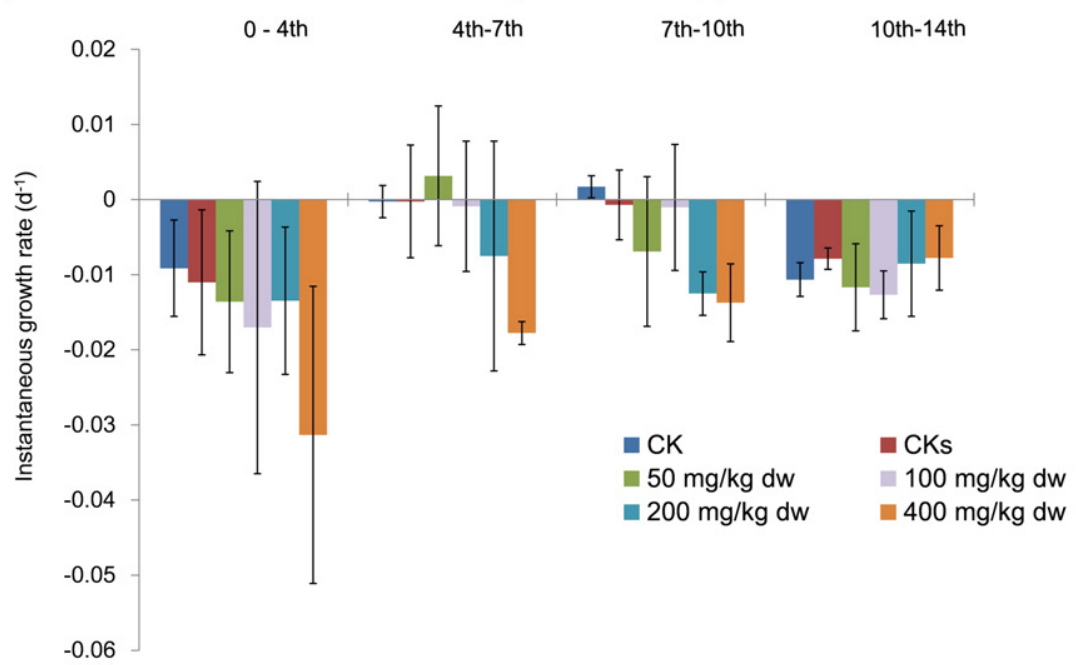

(b) HBCD

Exposure interval (d)

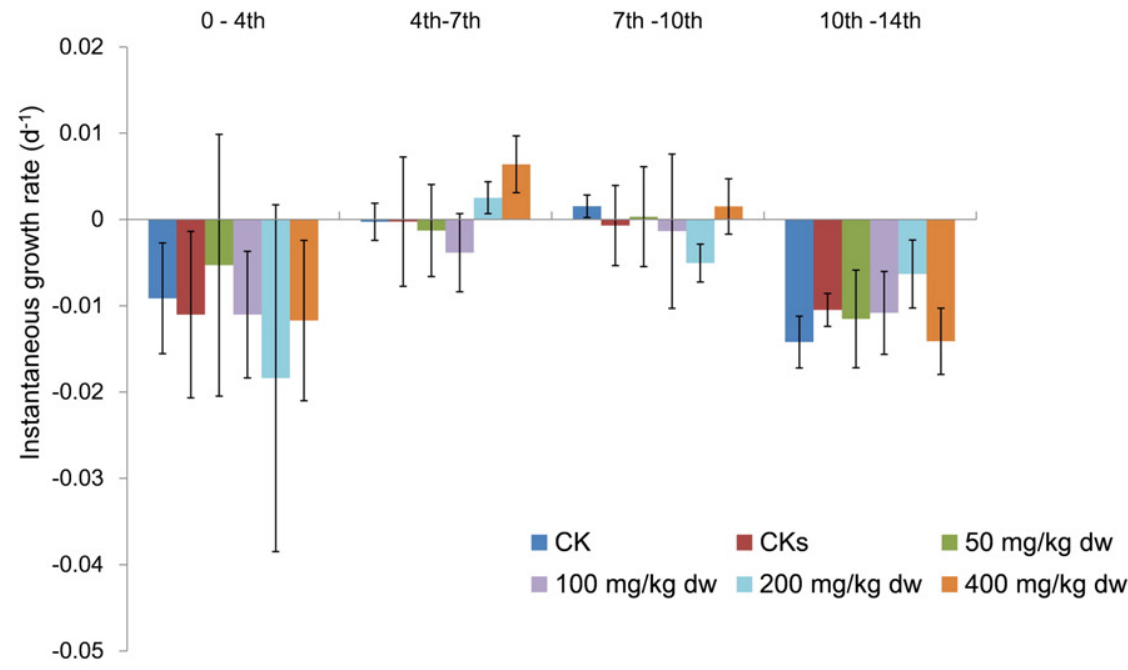

(c) BDE209

Exposure interval (d)

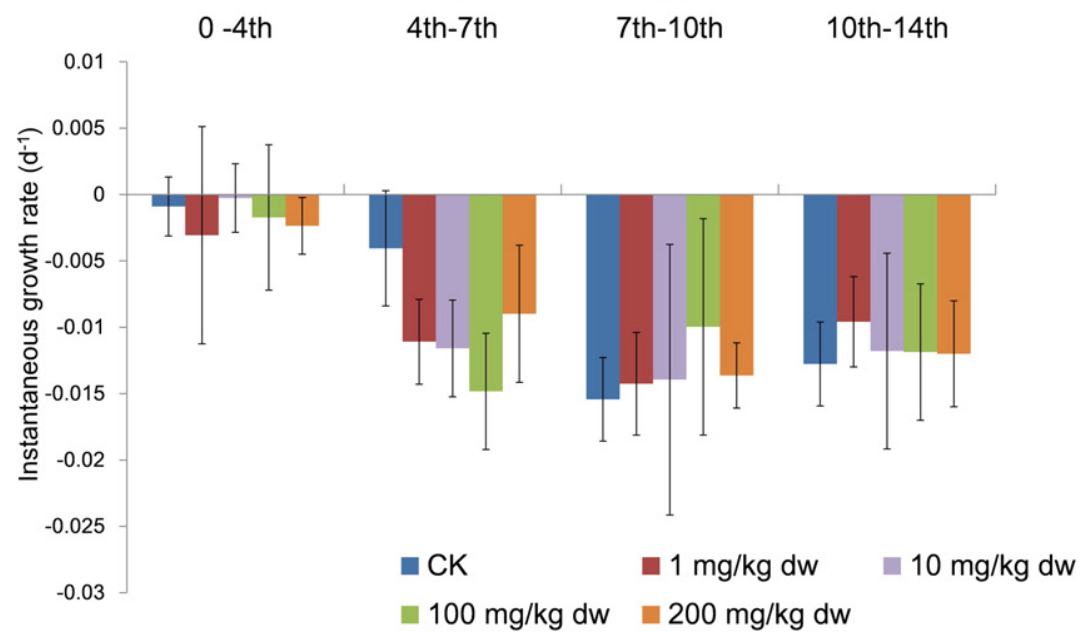

Fig. 2. Growth rates of earthworms exposed to TBBPA (a), HBCD (b) and BDE-209 (c) over different exposure intervals. 


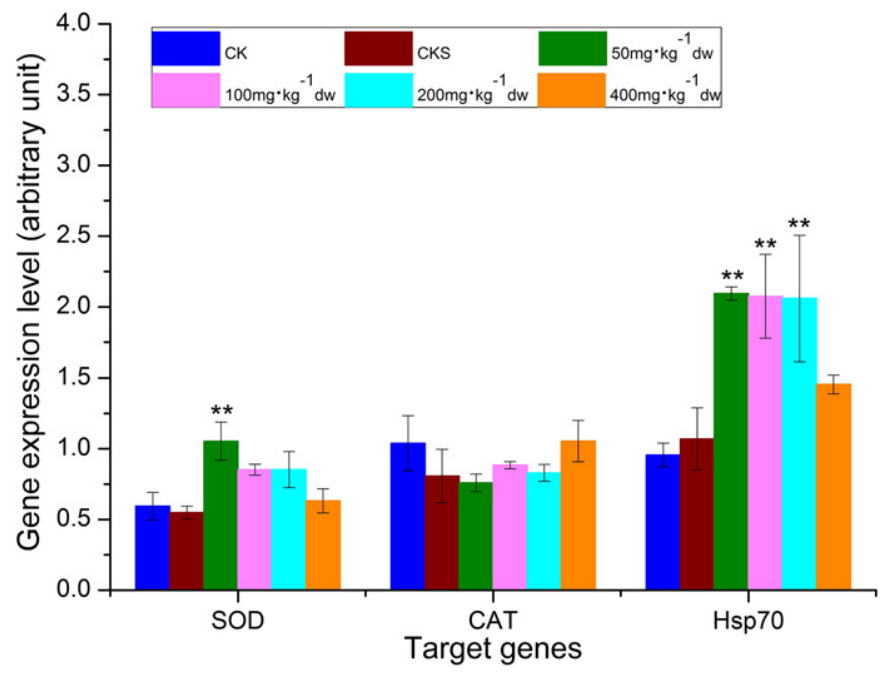

Fig. 3. Changes in target genes in earthworm Eisenia fetida tissues with different TBBPA treatments after 14 day exposure. ( ${ }^{* *} \mathrm{P}<0.01$ compared with the controls group).

\section{Discussion}

Mortality and biomass change are applied frequently for assessing the toxicity of pollutants since they show the responses of organisms reliably and are easy to detect. In this study, the earthworms survived in all the BFR treatments, meaning that the nonlethal effects of the selected BFRs on earthworms were observed.

The effects of TBBPA and HBCD on growth of earthworms have been scarcely reported. PBDEs are the most extensively investigated BFRs and evidences showed that some monomers of PBDEs significantly inhibited the growth of the earthworm (E. fetida). The authors found that the growth inhibition rates of E. fetida treated by $400 \mathrm{mg} / \mathrm{kg}$ dw BDE 47 reached $36.4 \%$ after 14-day exposure (Xu et al., 2015). BDE 71 $(1000 \mathrm{mg} / \mathrm{kg} \mathrm{dw})$ had significant effects on growth $(\mathrm{GI}=25 \%)$ on E. fetida after 14-day exposure (Zhu et al., 2009). In this study, the growth of earthworms treated by TBBPA at 200 and $400 \mathrm{mg} / \mathrm{kg} \mathrm{dw}$ was inhibited at rates of $13.7 \%$ and $22.0 \%$ respectively, while no significant growth inhibition by HBCD (at concentration of $50-400 \mathrm{mg} / \mathrm{kg}$ ) and BDE 209 (at concentration of 1-200 mg/kg) was noticed (Fig. 1). The growth inhibition by exposure to the high concentration of TBBPA may be explained by the strategy of reducing food intake to avoid toxins and consuming more energy to combat deleterious effects of

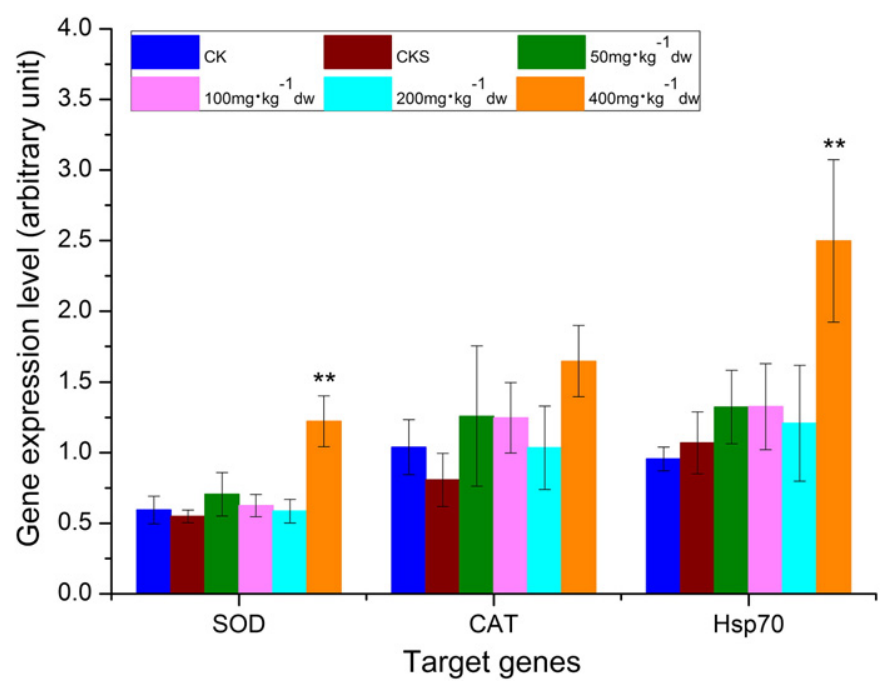

Fig. 4. Changes in target genes in earthworm Eisenia fetida tissues with different $\mathrm{HBCD}$ treatments after 14 day exposure. ${ }^{* *} \mathrm{P}<0.01$ compared with the control group).

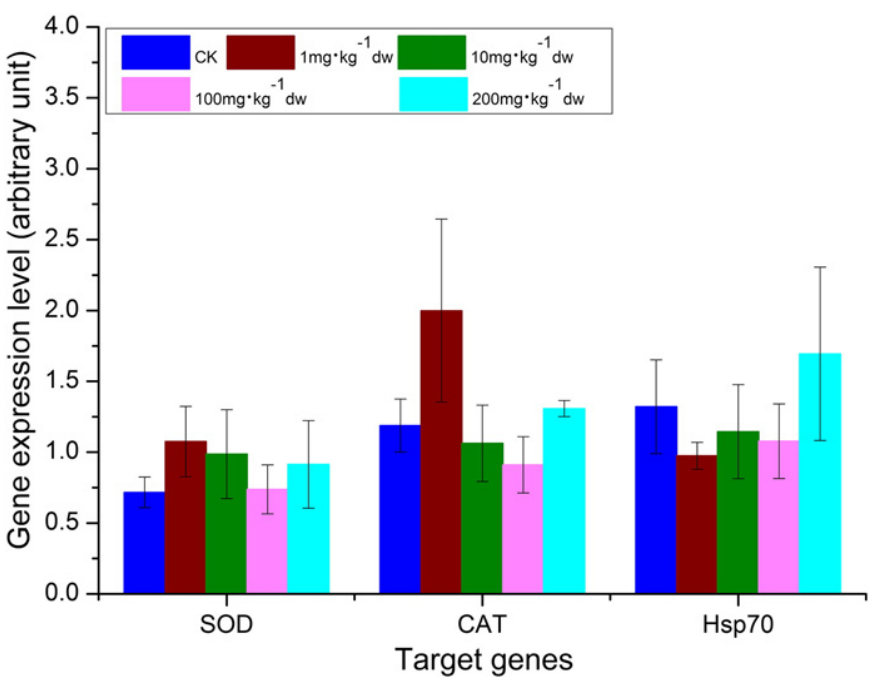

Fig. 5. Changes in target genes in earthworm Eisenia fetida tissues with different BDE 209 treatments after 14 day exposure.

contaminants, which was observed in crayfish (Rowe et al., 2001) and isopods (Porcellio dilatatus) (Ribeiro et al., 2001). The absence of growth inhibition in earthworm exposed to BDE 209 over the 14-day exposure in the present research is in agreement with previous report of BDE 209 (1000 mg/kg dw) on growth of the earthworms (E. fetida) after 28-day exposure (Xie et al., 2013).

The growth rates observed during the $0-14$ day exposure period help to understand the dynamics of growth inhibition to earthworms. The growth rates for 0-4th day had a negative value, decreased with the increase of TBBPA dose and significantly lower than those during the 4th-7th, 7th-10th, and 10th-14th days (Fig. 2a), it indicated that the growth inhibition appeared during the first 4 days of exposure to TBBPA, and it increased with the increase of TBBPA dose. Lower growth rates of earthworms exposed to HBCD were appeared at 0-4th day, while that of BDE 209 appeared later at 4th-7th days, possible reflecting the different absorption rates of the two BFRs by earthworms. However, no significant difference between controls and HBCD or BDE 209 groups of earthworms were shown during each of the exposure periods, indicating that the earthworms' growth was inhibited by nutrient deficiency or the other environmental factors, but not by the exposure to HBCD or BDE 209.

Oxidative stress can generate DNA damage and produce oxidative damage to macromolecules, leading to apoptotic mechanisms and finally damaging different cellular organelles (Sabatini et al., 2009). Oxidative stress is generated by the excessive reactive oxygen species (ROS) in living organisms, caused by exposure to heavy metals and organic contaminants (Saint-Denis et al., 2001; Lin et al., 2010). Oxidative stress was produced in earthworms exposed to BDE 209, HBCD and TBBPA by the generation of excessive hydroxyl radical ROS (Xue et al., 2009; Jin et al., 2010; Marvin et al., 2011; Xie et al., 2011; Zhang et al., 2014).

To scavenge ROS and combat oxidative stress, organisms possess antioxidant defense mechanisms. Superoxide dismutase (SOD) converts superoxide radical to hydrogen peroxide, thereby protecting cells from the toxic effects of superoxide radical (Liu et al., 2011; Hackenberger et al., 2012). The up-regulation of SOD gene expression indicates an adaptive onset of the antioxidant defense system in zebrafish to methylmercury (Gonzalez et al., 2005), in earthworms exposed to BDE 47 (Xu et al., 2015) and tonalide (AHTN) (Chen et al., 2011b). In this study, the significant up-regulation $(P<0.01)$ of SOD expression level was observed in earthworms exposed to TBBPA at $50 \mathrm{mg} / \mathrm{kg} \mathrm{dw}$ and to HBCD at $400 \mathrm{mg} / \mathrm{kg} \mathrm{dw}$, indicating that transcription of SOD might be stimulated by oxidative stress generated by superoxide anion radical and the enhanced SOD gene expression was required to protect earthworms from oxidative stress and to counteract 
ROS toxicity. That there is no variation of SOD expression level exposed to BDE 209 and low dose HBCD shows the lack of the oxidative stress on earthworms.

Catalase (CAT) is one of the important antioxidant enzymes which can decompose hydrogen peroxide into oxygen and water. Previous reports have shown the up-regulation of CAT expression level in oysters exposed to cadmium (Jo et al., 2008), in earthworms exposed to AHTN (Chen et al., 2011a) to detoxify the oxidative stress, and its downregulation in earthworms exposed to BDE 47 (Xu et al., 2015) when the generated superfluous ROS exceeds the capacity of scavenging ROS by CAT. In the present research, there is no variation of CAT gene expression in the earthworms in all the TBBPA, HBCD and BDE 209 treatments, indicating a balance of generation and scavenge of hydrogen peroxide radical in earthworms.

Heat shock proteins (Hsps) participate in multiple biological processes by promoting the proper folding of newly synthesized polypeptides into functional proteins and the repair or disposal of misfolded, damaged, proteins. In the present research, the expression of Hsp70 gene was significantly up-regulated when earthworms were exposed to TBBPA at concentrations of $50-200 \mathrm{mg} / \mathrm{kg} \mathrm{dw}$ and HBCD at $400 \mathrm{mg} /$ $\mathrm{kg} \mathrm{dw}$, but no variation when exposed to BDE 209. The results are contrary to the research in earthworms exposed to BDE 47 (Xu et al., 2015) and in aquatic animals exposed to 4-nonylphenol, 4-t-octylpheno (Rhee et al., 2009), carbon tetrachloride and fenitrothion (Lee et al., 2006), but are in agreement with researches on up-regulation of Hsp70 gene expression in copepod exposed to bisphenol A (Rhee et al., 2009), in earthworms induced by the exposure of heavy metals (Homa et al., 2007). These results all provide evidence that the Hsp70 gene expression is involved in oxidative stress responses. The results of this work also suggest the protective roles of Hsp70 in oxidative stress induced by TBBPA and HBCD in earthworms.

The comparative analysis of the different responses of growth, SOD gene expression, Hsp70 gene expression of earthworms to the BFRs may help to understand the toxicity order of TBBPA, HBCD and BDE 209. Only TBBPA significantly inhibited the growth of earthworms, with HBCD and BDE 209 showing no toxic effects on the growth; the SOD gene expression level was up-regulated by exposure to TBBPA at $50 \mathrm{mg} / \mathrm{kg}$ dw (1.77-fold, $\mathrm{P}<0.01)$, and to HBCD at $400 \mathrm{mg} / \mathrm{kg}(2.06-$ fold, $\mathrm{P}<0.01$ ), but no up-regulation by exposure to BDE 209, it indicated that the toxicity of the BFRs to SOD gene expression was in decreasing order of TBBPA, HBCD and BDE 209; the gene expression levels of Hsp 70 in TBBPA treatments were up-regulated in 50,100 , and $200 \mathrm{mg} / \mathrm{kg}$ $\mathrm{dw}$ groups, the up regulation appeared at $400 \mathrm{mg} / \mathrm{kg} \mathrm{dw}$ HBCD and no up-regulation by exposure to BDE 209 was observed, TBBPA showed the greatest toxicity to Hsp 70 gene expression, followed by HBCD and BDE209.

In general, the toxicity integrating the growth inhibition and antioxidant response gene expression of the three BFRs ranks in the decrease order of TBBPA, HBCD and BDE 209. The difference may be related to their chemical properties (Table 2). Compared to HBCD and BDE 209, TBBPA is the smallest molecule, has the highest water solubility and lowest distribution coefficient between organic matter and water, so that it is most readily cross membranes, and has the highest rate of toxic effects. On the contrary, BDE 209 has the largest molecules, lowest water solubility and is extremely hydrophobic, tightly bound in soils, showing why BDE 209 has little effects on the growth and genes expression levels of earthworms. HBCD shows medium toxicity to the genes with its chemical properties ranking between TBBPA and BDE 209.

\section{Conclusions}

The growth of earthworms treated by TBBPA at 200 and $400 \mathrm{mg} /$ $\mathrm{kg} \mathrm{dw}$ was significantly inhibited. Little variation of CAT gene and significant up-regulation of Hsp70 and SOD gene expression levels were observed in earthworms exposed to TBBPA (Hsp70: at dose 50-200 $\mathrm{mg} / \mathrm{kg}$; SOD: at dose $50 \mathrm{mg} / \mathrm{kg} \mathrm{dw}$ ).
Table 2

Selected chemical properties of the BFRs.

\begin{tabular}{lllll}
\hline Chemicals & $\begin{array}{l}\text { Skeletal } \\
\text { formula }\end{array}$ & $\begin{array}{l}\text { Molecular } \\
\text { weight }\end{array}$ & $\begin{array}{l}\text { Water solubility } \\
(\mathrm{mg} / \mathrm{l})\end{array}$ & log Kow \\
\hline TBBPA & 543.9 & 4.16 & 4.5 \\
\hline BBCD & & & \\
\end{tabular}

Data sources: a) WHO: Environmental Health Criteria 172. Tetrabromobisphenol A and derivatives. Geneva, Switzerland: International Programme on Chemical Safety, World Health Organization; 1995;

b) Covaci et al. (2006). Hexabromocyclododecanes (HBCDs) in the Environment and Humans: A Review. Environmental Science \& Technology 40, 3679-3688.

c) WHO: Environmental Health Criteria 162. Brominated diphenylethers. Geneva, Switzerland: International Programme on Chemical Safety, World Health Organization; 1994.

SOD and Hsp70 gene expression was both up-regulated by HBCD at the concentration of $400 \mathrm{mg} / \mathrm{kg}$. No significant variation of growth and CAT gene transcript level by HBCD was observed.

The growth inhibition and all the target gene expression levels of the BDE 209 groups were not significantly different when compared with controls.

Assessed by growth inhibition and the changes in mRNA levels of encoding genes in earthworms, TBBPA showed the greatest toxicity, followed by HBCD and BDE 209. The results help to understand the molecular mechanism of antioxidant defense. The transcriptional responses of the antioxidant genes may provide early warning molecular biomarkers for identifying the BFR toxicity.

\section{Acknowledgments}

The authors are grateful for the support provided by the National Natural Science Foundation of China (Grant No. 41272487), the International S\&T Cooperation Program of China (Grant No. 2012DFA91150), and the Key Research Program of the Chinese Academy of Sciences (Grant No. KZZD-EW-TZ-12).

\section{References}

Brulle, F., Mitta, G. Cocquerelle, C. Vieau, D., Lemière, S., Leprêtre, A., Vandenbulcke, F, 2006. Cloning and real-time PCR testing of 14 potential biomarkers in Eisenia fetida following cadmium exposure. Environ. Sci. Technol. 40, 2844-2850.

Brulle, F. Morgan, A. Cocquerelle, C. Vandenbulcke, F. 2010. Transcriptomic underpinning of toxicant-mediated physiological function alterations in three terrestrial invertebrate taxa: a review. Environ. Pollut. 158, 2793-2808.

Chen, C., Xue, S., Zhou, Q., Xie, X., 2011a. Multilevel ecotoxicity assessment of polycyclic musk in the earthworm Eisenia fetida using traditional and molecular endpoints. Ecotoxicology 20, 1949-1958.

Chen, C., Zhou, Q., Liu, S., Xiu, Z., 2011b. Acute toxicity, biochemical and gene expression responses of the earthworm Eisenia fetida exposed to polycyclic musks. Chemosphere $83,1147-1154$

Covaci, A., Gerecke, A.C., Law, R.J., Voorspoels, S., Kohler, M., Heeb, N.V., Leslie, H., Allchin, C.R., de Boer, J., 2006. Hexabromocyclododecanes (HBCDs) in the environment and humans: a review. Environ. Sci. Technol. 40, 3679-3688.

Covaci, A., Voorspoels, S., Abdallah, M.A.-E., Geens, T., Harrad, S., Law, R.J., 2009. Analytical and environmental aspects of the flame retardant tetrabromobisphenol-A and its derivatives. J. Chromatogr. A 1216, 346-363.

Covaci, A., Harrad, S., Abdallah, M.A.E., Ali, N., Law, R.J., Herzke, D., de Wit, C.A., 2011. Novel brominated flame retardants: a review of their analysis, environmental fate and behaviour. Environ. Int. 37, 532-556.

de Wit, C.A., Alaee, M., Muir, D.C.G., 2006. Levels and trends of brominated flame retardants in the Arctic. Chemosphere 64, 209-233.

Gauthier, L.T., Hebert, C.E., Weseloh, D.V.C., Letcher, R.J., 2007. Current-use flame retardants in the eggs of herring gulls (Larus argentatus) from the Laurentian great lakes. Environ. Sci. Technol. 41, 4561-4567.

Gevao, B., Ghadban, A.N., Uddin, S., Jaward, F.M., Bahloul, M., Zafar, J., 2011. Polybrominated diphenyl ethers (PBDEs) in soils along a rural-urban-rural transect: sources, concentration gradients, and profiles. Environ. Pollut. 159, 3666-3672. 
Gonzalez, P., Dominique, Y., Massabuau, J.C., Boudou, A., Bourdineaud, J.P., 2005. Comparative effects of dietary methylmercury on gene expression in liver, skeletal muscle, and brain of the zebrafish (Danio rerio). Environ. Sci. Technol. 39, 3972-3980.

Hackenberger, B.K., Velki, M., Stepić, S., Hackenberger, D.K., 2012. The effect of formalin on acetylcholinesterase and catalase activities, and on the concentration of oximes, in the earthworm species Eisenia andrei. Eur. J. Soil Biol. 50, 137-143.

Homa, J., Olchawa, E., Stürzenbaum, S.R., John Morgan, A., Plytycz, B., 2005. Early-phase immunodetection of metallothionein and heat shock proteins in extruded earthworm coelomocytes after dermal exposure to metal ions. Environ. Pollut. 135, 275-280.

Homa, J., Stürzenbaum, S.R., Morgan, A.J., Plytycz, B., 2007. Disrupted homeostasis in coelomocytes of Eisenia fetida and Allolobophora chlorotica exposed dermally to heavy metals. Eur. J. Soil Biol. 43 (Supplement 1), S273-S280.

Jin, S., Yang, F., Hui, Y., Xu, Y., Lu, Y., Liu, J., 2010. Cytotoxicity and apoptosis induction on RTG-2 cells of 2,2',4,4'-tetrabromodiphenyl ether (BDE-47) and decabrominated diphenyl ether (BDE-209). Toxicol. in Vitro 24, 1190-1196.

Jo, P.G., Choi, Y.K., Choi, C.Y., 2008. Cloning and mRNA expression of antioxidant enzymes in the Pacific oyster, Crassostrea gigas in response to cadmium exposure. Comp. Biochem. Physiol. C: Toxicol. Pharmacol. 147, 460-469.

Kemmlein, S., Herzke, D., Law, R.J., 2009. Brominated flame retardants in the European chemicals policy of REACH-regulation and determination in materials. J. Chromatogr. A 1216, 320-333.

Law, R.J., Herzke, D., Harrad, S., Morris, S., Bersuder, P., Allchin, C.R., 2008. Levels and trends of HBCD and BDEs in the European and Asian environments, with some information for other BFRs. Chemosphere 73, 223-241.

Law, R.J., Covaci, A., Harrad, S., Herzke, D., Abdallah, M.A.E., Fernie, K., Toms, L.-M.L., Takigami, H., 2014. Levels and trends of PBDEs and HBCDs in the global environment: status at the end of 2012. Environ. Int. 65, 147-158.

Lee, S.-M., Lee, S.-B., Park, C.-H., Choi, J., 2006. Expression of heat shock protein and hemoglobin genes in Chironomus tentans (Diptera, chironomidae) larvae exposed to various environmental pollutants: a potential biomarker of freshwater monitoring. Chemosphere 65, 1074-1081.

Lin, D., Zhou, Q., Xie, X., Liu, Y., 2010. Potential biochemical and genetic toxicity of triclosan as an emerging pollutant on earthworms (Eisenia fetida). Chemosphere 81, 1328-1333.

Liu, S., Zhou, Q., Wang, Y., 2011. Ecotoxicological responses of the earthworm Eisenia fetida exposed to soil contaminated with HHCB. Chemosphere 83, 1080-1086.

Marvin, C.H., Tomy, G.T., Armitage, J.M., Arnot, J.A., McCarty, L., Covaci, A., Palace, V., 2011 Hexabromocyclododecane: current understanding of chemistry, environmental fate and toxicology and implications for global management. Environ. Sci. Technol. 45, 8613-8623.

Ni, K., Lu, Y., Wang, T., Kannan, K., Gosens, J., Xu, L., Li, Q., Wang, L., Liu, S., 2013. A review of human exposure to polybrominated diphenyl ethers (PBDEs) in China. Int. J. Hyg. Environ. Health 216, 607-623.

Olsvik, P.A., Kristensen, T., Waagbø, R., Rosseland, B.O., Tollefsen, K.E., Baeverfjord, G., Berntssen, M.H.G., 2005. mRNA expression of antioxidant enzymes (SOD, CAT and GSH-Px) and lipid peroxidative stress in liver of Atlantic salmon (Salmo salar) exposed to hyperoxic water during smoltification. Comp. Biochem. Physiol. C: Toxicol. Pharmacol. 141, 314-323.

Pfaffl, M.W., 2001. A new mathematical model for relative quantification in real-time RT-PCR. Nucleic Acids Res. 29, 2002-2007.
Rhee, J.-S., Raisuddin, S., Lee, K.-W., Seo, J.S., Ki, J.-S., Kim, I.-C., Park, H.G., Lee, J.-S., 2009 Heat shock protein (Hsp) gene responses of the intertidal copepod Tigriopus japonicus to environmental toxicants. Comp. Biochem. Physiol. C: Toxicol. Pharmacol. 149 104-112.

Ribeiro, S., Sousa, J.P., Nogueira, A.J.A., Soares, A., 2001. Effect of endosulfan and parathion on energy reserves and physiological parameters of the terrestrial isopod Porcellio dilatatus. Ecotoxicol. Environ. Saf. 49, 131-138.

Rowe, C.L., Hopkins, W.A., Zehnder, C., Congdon, J.D., 2001. Metabolic costs incurred by crayfish (Procambarus acutus) in a trace element-polluted habitat: further evidence of similar responses among diverse taxonomic groups. Comp. Biochem. Physiol. C: Toxicol. Pharmacol. 129, 275-283.

Sabatini, S.E., Juárez, Á.B., Eppis, M.R., Bianchi, L., Luquet, C.M., Ríos de Molina, M.d.C., 2009. Oxidative stress and antioxidant defenses in two green microalgae exposed to copper. Ecotoxicol. Environ. Saf. 72, 1200-1206.

Saint-Denis, M., Narbonne, J.F. Arnaud, C. Ribera, D. 2001. Biochemical responses of the earthworm Eisenia fetida andrei exposed to contaminated artificial soil: effects of lead acetate. Soil Biol. Biochem. 33, 395-404.

Song, Y., Zhu, L.S., Wang, J., Wang, J.H., Liu, W., Xie, H., 2009. DNA damage and effects on antioxidative enzymes in earthworm (Eisenia foetida) induced by atrazine. Soil Biol. Biochem. 41, 905-909.

Webb, D., Gagnon, M.M., 2009. The value of stress protein 70 as an environmenta biomarker of fish health under field conditions. Environ. Toxicol. 24, 287-295.

Xie, X., Wu, Y., Zhu, M., Zhang, Y.-k., Wang, X., 2011. Hydroxyl radical generation and oxidative stress in earthworms (Eisenia fetida) exposed to decabromodipheny ether (BDE-209). Ecotoxicology 20, 993-999.

Xie, X., Qian, Y., Wu, Y., Yin, J., Zhai, J., 2013. Effects of decabromodiphenyl ether (BDE209) on the avoidance response, survival, growth and reproduction of earthworms (Eisenia fetida). Ecotoxicol. Environ. Saf. 90, 21-27.

Xiong, W. Ding, X, Zhang Y, Sun, Y, 2014. Ecotoxicological effects of a veterinary food additive, copper sulphate, on antioxidant enzymes and mRNA expression in earthworms. Environ. Toxicol. Pharmacol. 37, 134-140.

Xu, X., Shi, Y., Lu, Y., Zheng, X., Ritchie, R.J., 2015. Growth inhibition and altered gene transcript levels in earthworms (Eisenia fetida) exposed to 2,2',4,4'-tetrabromodiphenyl ether. Arch. Environ. Contam. Toxicol. 69, 1-7.

Xue, Y., Gu, X., Wang, X., Sun, C., Xu, X., Sun, J., Zhang, B., 2009. The hydroxyl radical generation and oxidative stress for the earthworm Eisenia fetida exposed to tetrabromobisphenol A. Ecotoxicology 18, 693-699.

Yang, Z.Z., Li, Y.F., Hou, Y.X., Liang, H.Y., Qin, Z.F., Fu, S., 2010. Vertical distribution of polybrominated diphenyl ethers (PBDEs) in soil cores taken from a typical electronic waste polluted area in South China. Bull. Environ. Contam. Toxicol. 84, 260-263.

Zhang, Y., Shen, G., Yu, Y., Zhu, H., 2009. The hormetic effect of cadmium on the activity of antioxidant enzymes in the earthworm Eisenia fetida. Environ. Pollut. 157, 3064-3068.

Zhang W., Liu, K. Chen, L, Chen, L, Lin, K., Fu, R., 2014. A multi-biomarker risk assessment of the impact of brominated flame retardant-decabromodiphenyl ether (BDE209) on the antioxidant system of earthworm Eisenia fetida. Environ. Toxicol. Pharmacol. 38, 297-304.

Zhu, S., Liu, M., Zhu, L., 2009. Single and combined toxicities of penta-BDE and cadmium to earthworm (Eisenia fetida) in soil. Sciencepaper Online. 